\title{
Has European Customs Union Agreement really affected Turkey's trade?
}

\section{Bilin Neyaptı , Fatma Taşkın \& Murat Üngör}

To cite this article: Bilin Neyaptı , Fatma Tașkın \& Murat Üngör (2007) Has European Customs Union Agreement really affected Turkey's trade?, Applied Economics, 39:16, 2121-2132, DOI: $10.1080 / 00036840600735390$

To link to this article: http://dx.doi.org/10.1080/00036840600735390

$$
\text { 册Published online: } 11 \text { Apr } 2011 .
$$

Submit your article to this journal $\pi$

Llll Article views: 385

Q View related articles ¿

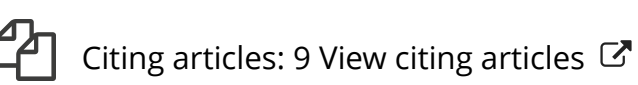




\title{
Has European Customs Union Agreement really affected Turkey's trade?
}

\author{
Bilin Neyaptı ${ }^{\mathrm{a}, *}$, Fatma Taşkın ${ }^{\mathrm{a}}$ and Murat Üngör ${ }^{\mathrm{b}}$ \\ ${ }^{a}$ Department of Economics, Bilkent University, 06800 Bilkent, Ankara, \\ Turkey \\ ${ }^{\mathrm{b}}$ Department of Economics, University of Southern California, $3620 \mathrm{~S}$. \\ Vermont Ave. KAP 300, Los Angeles, CA 90089, USA
}

The numerous discussions regarding the advantages and disadvantages of Turkey's becoming a member of the Customs Union has been inconclusive. The empirical analysis that mostly focus on the changes in the volume of trade without much regard to the conjectural changes have also been insufficient. This study attempts to shed light on this issue in a formal analysis of Turkey's international trade by empirically accounting for the changes before and after the Customs Union Agreement (CUA). In doing so, we explicitly account for the concurrent changes in the macroeconomic environment that may have affected Turkey's trade with the rest of the world. Our empirical findings indicate that CUA has not only positively impacted on Turkey's trade, but also led to changes in the behaviour of both exports and imports with regards to their responsiveness to underlying variables.

\section{Introduction}

The relationship between Turkey and initially the European Economic Cooperation (EEC) and later the European Union (EU) has started with the association agreement signed in Ankara, in September 1963. An additional protocol, signed in November 1970 and put into effect in January 1973, specified the time schedule for the steps Turkey will take in the next 22 years to join the Customs Union (CU) (Berument et al., 2001). In December 1995, the European Parliament took the decision to finalize the customs agreement with Turkey, while the final stage of CU was arrived in January 1996. Turkey's joining the CU has been considered as a step towards its full membership to the EU, which is envisioned to not only increase the level of wealth in Turkey but also reduce the risk premium and encourage the volume of capital inflows.

Customs Union theory has been defined as a branch of the tariff theory that deals with the effects of geographical discrimination (Lipsey, 1970; Chacholiades, 1978). Suggested by this definition, $\mathrm{CU}$ involves preferential trading agreements that imply zero duty among members on imports of goods and services and a common external tariff.

Turkey started to implement trade liberalization policies in the 1980s, after an extended period of an inward-looking development strategy. During the 1980s, like many other countries, Turkish economy also underwent a series of trade reforms, including

*Corresponding author. E-mail: neyapti@bilkent.edu.tr 
abandoning the fixed exchange rate regime. ${ }^{1}$ With the Customs Union Agreement (CUA), Turkey's custom duties, quantitative restrictions and other measures with similar effects on the trade with the EU were eliminated. In addition, Common Custom Tariff structure was accepted and necessary steps were taken for a gradual adoption of similar preferential trade agreements that exist between EU and with the third countries. However, CUA excluded agricultural goods and free circulation of agricultural products was postponed until Turkey aligned its policies to the EU's Common Agricultural Policy.

The change in the development policies from import substitution to export oriented policies led to a significant decline in protectionist measures even before the CUA came into effect. Another major component of the CUA, which is expected to have a significant impact on Turkey's trade, was the removal of the technical barriers to trade. In this respect, Turkey accepted to adopt, within a specific time frame, community mechanisms regarding issues such as standardization, quality and accreditation. Turkey also planned to harmonize the rules and regulations concerning the economic environment, such as intellectual and industrial property rights, competition rules, state aid, the Custom code and administrative cooperation. Hence, it is not possible to consider the CUA as solely a change in the tariff structure but a series of changes, which will have a cumulative impact on total trade level and behaviour. ${ }^{2}$

Harrison et al. (1996), suggest that improved access to third country markets would be the biggest gain from the customs union arrangement. Using a comparative static computable general equilibrium model for Turkey, they estimate that Turkey stands to gain between 1 and $1.5 \%$ of GDP annually from CU. By contrast, Mercenier and Yeldan (1997), also in a general equilibrium exercise, characterize the net impact of the CUA as undesirable for Turkey. Also in a general equilibrium framework, Bekmez (2002) suggests that $\mathrm{CU}$ would lead to revenue losses for the government sector and in GDP, though it would benefit the private sector.

While the foregoing works are based on projections under various economic scenarios, this article takes the factual evidence since the implementation of the $\mathrm{CU}$ as the basis of the analysis of its impact on Turkish trade. We model imports and exports for the Turkish economy conventionally, though with the necessary modifications that enables us to investigate changes with regards to both the volume and behavioural aspects, separately for the $\mathrm{CU}$ period and for the EU group of countries.

Our analysis involves more than 150 countries between 1980 and 2001, yielding an unbalanced panel data set comprised of more than 2000 observations. By analysing Turkey's trade in the CU period and with the EU countries in an all-encompassing data set that consists of Turkey's trade with all countries, we refrain from possible biases that could possibly arise due to the global trends with regards to increasing trade volumes, which may result form increasing income levels or decreasing exchange rate misalignments.

The evidence in this article reveals that, after controlling for the (significant) effects of real exchange rate (RER) and income, especially exports of Turkey have been positively affected by the CU. Moreover, we observe that income elasticity of both exports to and imports from all countries other than the EU are lower in the $\mathrm{CU}$ period. Income elasticities of Turkish exports to and imports from the EU countries, however, have generally been higher than that from the rest of the world. On the other hand, while the effect of RER on Turkey's exports to the EU, and not for the rest of the countries, is stronger for the $\mathrm{CU}$ period, real exchange rate looses its significance for imports during the $\mathrm{CU}$ period in especially the nonEU set of countries. In addition, we observe that political stability and good governance in countries Turkey trades would have contributed to trade.

The organization of the rest of this article is as follows. In Section II, we provide a close look at the data and methodology used in this article. Section III presents the empirical results and, finally, Section IV concludes.

\section{Data and Methodology}

Our data set is an unbalanced panel that comprises more than 150 countries and more than 2000 country-year observations that range over the years 1980-2001. The data set mainly includes Turkey's imports from and exports to other countries; real bilateral exchange rates $(\mathrm{RER})^{3}$ and GDP

\footnotetext{
${ }^{1}$ The quota list was removed in 1981 and was replaced by an import programme in 1984, which increased tariffs for consumption goods but reduced them for intermediate and capital goods (Baysan and Blitzer, 1991).

${ }^{2}$ See, for example, Bayar et al. (2000).

${ }^{3}$ Calculated as: nominal (official) exchange rate (foreign currency units per TL) $\times[$ Turkish CPI/Foreign CPI], where all figures are indices based in 1995.
} 
levels in Dollars (source: World Bank). In addition, we form a dummy for the $\mathrm{CU}$ period (CU) that takes the value of 1 for 1996 till 2001 and zero otherwise; and another dummy that takes the value of 1 for the 14 EU countries ${ }^{4}$ (DEU), and zero otherwise.

Table 1 provides data on Turkey's total exports to and imports from both the EU and nonEU country groups since the 1980s. In addition, the column $(X / M) * 100$ shows the ratio of imports that can be financed through export revenues. The table clearly shows that Turkey's exports to and imports from both EU and nonEU countries have increased steadily since 1980 , conforming to the global trends towards growing economic integration. Moreover, as of 2001, there are no major differences between Turkey's trade volume with the EU and that with the rest of the world. The financing ratio for imports also does not appear to diverge much between the EU trade and the nonEU trade.

The export and import data in percentages of GDP also show a steadily growing trend over time for both sets of countries. Moreover, Turkey's trade imbalances with both sets of countries have grown wider during the 1990s as compared to the 1980s. ${ }^{5}$ Appendix Table A1 shows Turkey's GDP and real exchange rate in terms of Dollars. It is observed that, if 1995 is selected as the base year for the real exchange rate, then Turkish Lira (TL) appears overvalued in the early 1990s; undervalued in 1994 since crises led to the overshooting of TL; was in long-run equilibrium between 1996 and 2000; and became undervalued again in $2001 .^{6}$ In addition, there are notable fluctuations in the GDP, be it in Dollar terms or in TL, which coincide with the years of financial crises of 1994 and 2001 and the earthquake (1999) in Turkey. These episodes should explicitly be taken into account for an accurate behavioural analysis of exports and imports, which is what we do next.
In the spirit of Goldstein and Khan (1976), Murray and Ginman (1976), Bond (1987) and Brada et al. (1997), who used the level of income besides some relative price concept to estimate the export or import demand functions, ${ }^{7}$ we estimate the following models, where $X T_{i t}\left(M T_{i t}\right)$ stands for exports (imports) of Turkey to (from) country $i$ at time $t ; T$ stands for Turkey, rer is the real exchange rate of $\mathrm{TL}$ with respect to other currencies; ${ }^{8}$ ln is natural logarithm and; dеиси is the interactive dummy between CU and DEU.

$$
\begin{aligned}
& \ln X T_{i t}=\alpha_{0 i}+\alpha_{1}(\ln g d p)_{i t}+\alpha_{2}(\ln r e r)_{i t} \\
& \ln X T_{i t}= \alpha_{0 i}+\alpha_{1}(\ln g d p)_{i t}+\alpha_{2}(\ln r e r)_{i t}+\alpha_{3}(c u) \\
&+\alpha_{4}\left(d e u^{*} c u\right)_{i t} \\
& \ln X T_{i t}= \alpha_{0 i}+\alpha_{1}(\ln g d p)_{i t}+\alpha_{2}(\ln r e r)_{i t}+\alpha_{3}(c u) \\
&+\alpha_{4}\left(d e u^{*} c u\right)_{i t}+\alpha_{5}\left(c u^{*} \ln g d p\right)_{i t} \\
&+\alpha_{6}\left(\text { cu }^{*} \ln r e r\right)_{i t}+\alpha_{7}\left(d e u c u^{*} \ln g d p\right)_{i t} \\
&+\alpha_{8}\left(d e u c u^{*} \ln r e r\right)_{i t} \\
& \ln M T_{i t}=\beta_{0 i}+\beta_{1}(\ln g d p T)_{i t}+\beta_{2}(\ln r e r)_{i t} \\
& \ln M T_{i t}= \beta_{0 i}+\beta_{1}(\ln g d p T)_{i t}+\beta_{2}(\ln r e r)_{i t}+\beta_{3}(c u) \\
&+\beta_{4}\left(d e u^{*} c u\right)_{i t} \\
& \ln M T_{i t}= \beta_{0 i}+\beta_{1}(\ln g d p T)_{i t}+\beta_{2}(\ln r e r)_{i t}+\beta_{3}(c u)_{i t} \\
&+\beta_{4}\left(d e u^{*} c u\right)_{i t}+\beta_{5}\left(c u^{*} \ln g d p T\right)_{i t} \\
&+\beta_{6}\left(c u^{*} \ln r e r\right)_{i t}+\beta_{7}\left(d e u c u^{*} \ln g d p T\right)_{i t} \\
&+\beta_{8}\left(d e u c u^{*} \ln r e r\right)_{i t}
\end{aligned}
$$

Equations 1.1 and 2.1 are our baseline equations which estimate income and price elasticities for Turkish exports and imports, respectively. The structural shifts with respect both the CU period and the EU countries are examined in Equations 1.2 and 2.2. Equations 1.3 and 2.3 are the most complete models in which we investigate the effect of CU on the behaviour of exports and imports of Turkey beyond the structural shifts. ${ }^{9}$ Since the

\footnotetext{
${ }^{4}$ We combined the data for Belgium and Luxembourg for the reason that data on Turkey's bilateral trade with the two countries exists in a combined form.

${ }^{5} \mathrm{~A}$ closer inspection reveals that while the share of trade (both imports and exports) in agricultural goods with the EU countries have declined in the second half of the 1990s, the share of imports and exports in industrial goods have increased, also affecting the composition of Turkey's total trade in the same manner (see Table A2).

${ }^{6}$ The findings of Doroodian et al. (2002) confirm these observations. Estimating the equilibrium real exchange rate (ERER) and comparing it with the real effective exchange rate (REER), the authors report that REER was undervalued prior to 1989 and overvalued thereafter till 1994, while the misalignments in REER were corrected over the long term. On the other hand, employing a new methodology, Ozlale and Yeldan (2004) argue that the Turkish Lira was overvalued mainly between 1995 and 1997. While the misalignments subsided thereafter, a major undervaluation is observed in 2001.

${ }^{7}$ Both Goldstein and Khan (1976) and Murray and Ginman (1976) use the ratio of import prices to domestic prices to estimate the import demand function; likewise, Bond (1987) and Brada et al. (1997) use the ratio of export prices to world prices to estimate the export function.

${ }^{8}$ An increase in rer indicates real appreciation of the TL.

${ }^{9}$ We cannot add the political stability and governance terms to the fixed effect formulation. However, though econometrically inferior, OLS estimation is performed to analyse the effects of these terms, whose results are reported briefly below.
} 
Table 1. Selected trade indicators of Turkey (current US\$, in billions)

\begin{tabular}{|c|c|c|c|c|c|c|}
\hline \multirow[b]{2}{*}{ Year } & \multicolumn{3}{|c|}{ EU countries } & \multicolumn{3}{|c|}{ NonEU countries } \\
\hline & $X$ & $M$ & $(X / M) * 100$ & $X$ & $M$ & $(X / M) * 100$ \\
\hline 1980 & 1.38 & 2.59 & 53 & 1.53 & 5.32 & 29 \\
\hline 1981 & 1.69 & 2.81 & 60 & 3.02 & 6.12 & 49 \\
\hline 1982 & 1.92 & 2.78 & 69 & 3.82 & 6.06 & 63 \\
\hline 1983 & 2.19 & 2.98 & 73 & 3.54 & 6.25 & 57 \\
\hline 1984 & 2.95 & 3.54 & 83 & 4.19 & 7.22 & 58 \\
\hline 1985 & 3.40 & 4.18 & 81 & 4.56 & 7.16 & 64 \\
\hline 1986 & 3.42 & 4.86 & 70 & 4.03 & 6.25 & 65 \\
\hline 1987 & 5.13 & 6.07 & 84 & 5.06 & 8.08 & 63 \\
\hline 1988 & 5.36 & 6.30 & 85 & 6.30 & 8.03 & 78 \\
\hline 1989 & 5.68 & 6.49 & 88 & 5.94 & 9.31 & 64 \\
\hline 1990 & 7.20 & 9.93 & 73 & 5.76 & 12.38 & 47 \\
\hline 1991 & 7.38 & 9.90 & 75 & 6.22 & 11.15 & 56 \\
\hline 1992 & 7.91 & 10.66 & 74 & 6.80 & 12.21 & 56 \\
\hline 1993 & 7.60 & 13.87 & 55 & 7.74 & 15.56 & 50 \\
\hline 1994 & 8.69 & 10.92 & 80 & 9.41 & 12.35 & 76 \\
\hline 1995 & 11.08 & 16.86 & 66 & 10.55 & 18.85 & 56 \\
\hline 1996 & 11.50 & 22.34 & 51 & 11.72 & 21.29 & 55 \\
\hline 1997 & 12.25 & 24.84 & 49 & 14.01 & 23.72 & 59 \\
\hline 1998 & 13.72 & 24.46 & 56 & 13.26 & 21.47 & 62 \\
\hline 1999 & 14.35 & 21.42 & 67 & 12.24 & 19.26 & 64 \\
\hline 2000 & 14.51 & 26.61 & 55 & 13.26 & 27.89 & 48 \\
\hline 2001 & 16.12 & 18.28 & 88 & 15.22 & 23.12 & 66 \\
\hline
\end{tabular}

Note: The figures are based on merchandise exports and imports.

Source: World Bank.

various trading partners exhibit different characteristics that may constitute parametric shifts, and since the majority, if not the entirety, of Turkey's trading partners are included in the data set, our methodology utilizes fixed effects model for the estimation of both the export and import functions. ${ }^{10}$

\section{Regression Results}

Regressions (1.1) to (2.3) reported in Table 2 use cross-country and time-series data on bilateral trade of Turkey with all the countries in the sample. The estimation results using fixed effects methodology indicate that Turkey's exports and imports behave according to the predictions of the theory; both exports and imports are sensitive to income and price changes. In the estimation of the export equation (Equation 1.1), the income elasticity and elasticity of exports with respect to real exchange rates, which is taken a measure of relative price changes (real exchange rate appreciates if Inrer increases) are both statistically significant at $1 \%$ significance level. The positive income elasticity is above 2.0 and negative price elasticity is approximately -0.67 , showing that Turkish bilateral exports are income elastic but price inelastic. Similar results are obtained in the estimation of the import function (Equation 2.1 reported in Table 2). The domestic income elasticity is above unity and relative price elasticity is less than one, both of which are significant at $1 \%$ level.

In regressions (1.2) and (2.2) reported in Table 2, we observe that the CUA had a positive and significant impact both on the Turkish exports and imports and on the direction of trade; in both export and import estimations, the coefficients of the $c u$ dummy are positive and statistically significant at $1 \%$. These results demonstrate that CUA and the changes following the agreement resulted in a significant increase in the trade volumes of Turkey. ${ }^{11}$ The empirical evidence further points out that the changes in trade volume have been coupled

\footnotetext{
${ }^{10}$ See Kennedy (1997) for example. Both Hausman (1978) and joint F-tests support the appropriateness of this choice (available from the authors).

${ }^{11}$ A similar finding is reported by Martinez-Zarzoso and Nowak-Lehmann (2003) in the context of Mercosur-European Union trade flows. In a more general context, Endoh (2005) also argues that global system of trade preferences, another from of preferential trade agreement among developing countries, has also been conducive to an increase in trade value.
} 


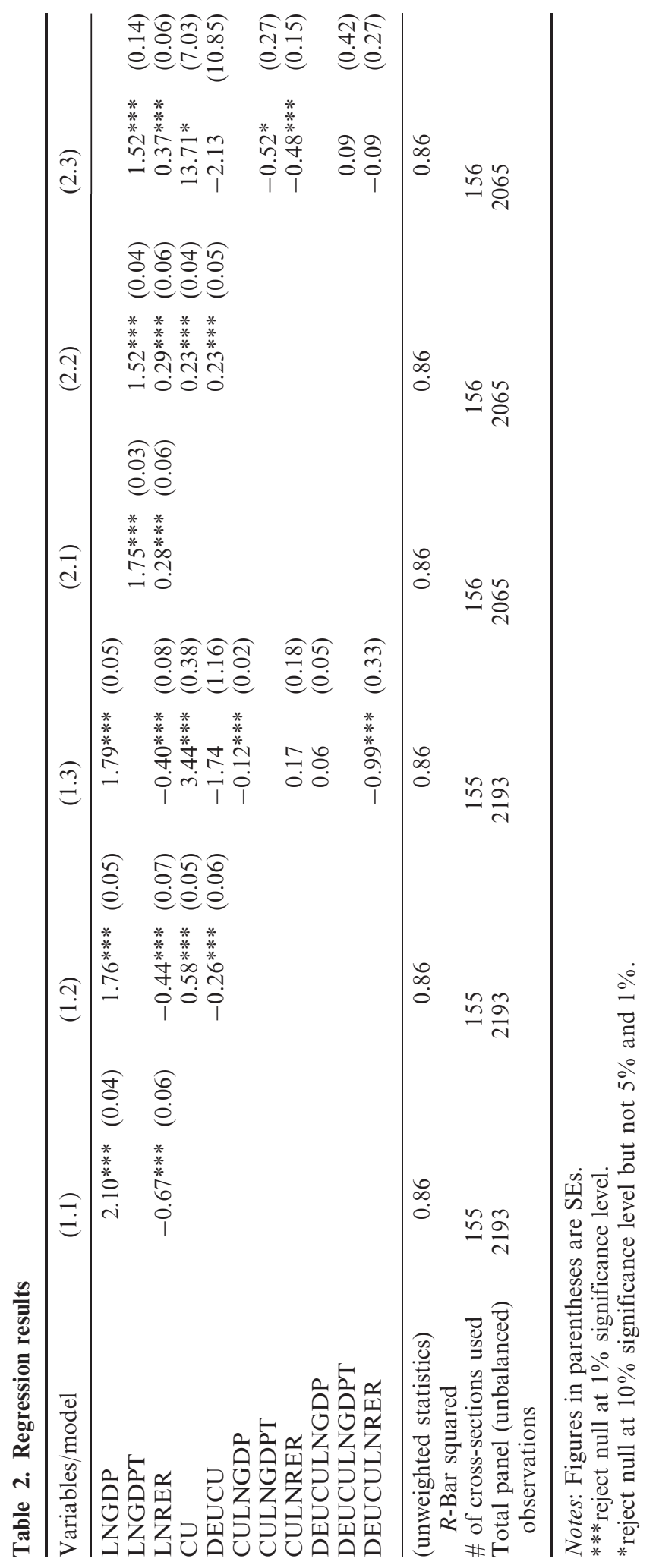


with significant changes in the direction of trade; the significant and negative sign of the interactive dummy variable $c u * d e u$ in the export equation and its significant and positive coefficient in the import equation indicate that the increase in exports to the $\mathrm{EU}$ is less and the increase in imports from the EU is more than the average increase in Turkey's exports in the period following the CUA.

Custom Union Agreement not only changed the tariff structure with respect to all countries, but also brought a set of new regulations regarding the conduct of trade relations. Even though the evidence above indicates that trade has increased after the CUA, the question still remains as to whether this change in trade policy brought about an additional structural change in export supply and import demand in Turkey. To test these possible behavioural changes, the responsiveness of imports and exports to income and price variables needs to be examined. To do this, income and price variables are also used interactively with the CU dummy in regressions (1.3) and (2.3).

The statistically significant coefficients ${ }^{12}$ estimated for these interactive variables demonstrate that some of the behavioural patterns are modified after CUA. Turkish exports became less responsive to both income changes of their trade partners ${ }^{13}$ and to price changes. A stronger picture emerges for Turkey's import demand; after CUA, the price responsiveness of imports significantly declined to an extent that import demand became insensitive to price changes. ${ }^{14}$ There is also somewhat weak evidence that the income elasticity of imports is lower after $\mathrm{CU} .{ }^{15}$

Did the CUA result change in the behaviour of the EU demand for Turkish exports and Turkish demand for the EU imports? The estimation results indicate that Turkey's trade with Europe shows different sensitivities than the rest of the countries during the period of CU. The most significant difference between EU and other countries is in the price responsiveness of exports. Following the CUA, the sensitivity of exports to price changes increased statistically significantly: by 0.99 in absolute value, for the EU countries. Hence, following CU, demand for Turkish exports in the EU countries have become more price sensitive, indicating that in the competition that Turkish exports products are facing from the EU market, the price factor has become more important. Increasing manufacturing content of Turkish exports can also be part of the explanation for the increased price elasticity. Indeed, these behavioural changes appear to account for the trade diversion effect away for the EU, which was observed in regression (1.2). ${ }^{16}$ Finally, we observe that neither price elasticity of Turkish imports nor income elasticities of both exports and imports show any statistically significant difference between EU and the rest of the countries.

The current study also examines the impact on the Turkey's bilateral trade of the economic and financial crises that occurred in the Turkish economy. Turkey underwent two major economic crises since the liberalization period: in 1994 and in 2001, both of which were associated with large real income and RER shocks. The common features of these periods were that the economic conditions preceding the crisis led to overvaluation of the TL and building up of the expectations of devaluation, followed by a sudden and almost overnight collapse of the value of the currency. This led to a major deterioration in real income and a decline in the overall demand. Another event that had large economic repercussions was the major earthquake of 1999, which not only curtailed the production capacity but the built-up efforts absorbed a significant amount of the financial resources and led to a notable decrease in the overall aggregate demand level.

Effects of these crises periods are empirically tested by the inclusion of dummies for each of these events into the exports and import equations. Regressions reported in Table 3 reveal that the 1994 crisis has led to significant increases in both total exports and imports of Turkey. For the 2001 crisis, there is a significant increase in exports but the significance in the change in imports is not robust; indeed the significance of the 2001 dummy disappears in Equation 2.3. Both of these results can be explained by the timing of the crisis and the month in which the major devaluation occurred. The shock to the value

\footnotetext{
${ }^{12}$ See Table A3 for significance tests of the sum of the coefficient estimates.

${ }^{13}$ With a 0.12 decline in the income elasticity of demand.

${ }^{14}$ According to the result of the Wald test, it is not possible to reject the hypothesis that the sum of the two price coefficients is in fact zero.

${ }^{15}$ The regression analysis that includes only the interactive CU dummy with the income and price variables, reveals similar results and shows that these parameter estimates are quite robust to the addition of other interactive terms and dummy variables.

${ }^{16}$ Berument and Dincer (2005) state that appreciation of Euro against US Dollar improves the trade balance of Turkey, since currency composition of Turkey's exports are more heavily in Euros than in Dollars as opposed to its imports, which are more heavily in Dollars. Coupled with this observation, increased RER sensitivity of Turkish exports during the CU period accentuates the positive effect of a decrease in the Euro-Dollar parity on the trade balance of Turkey.
} 


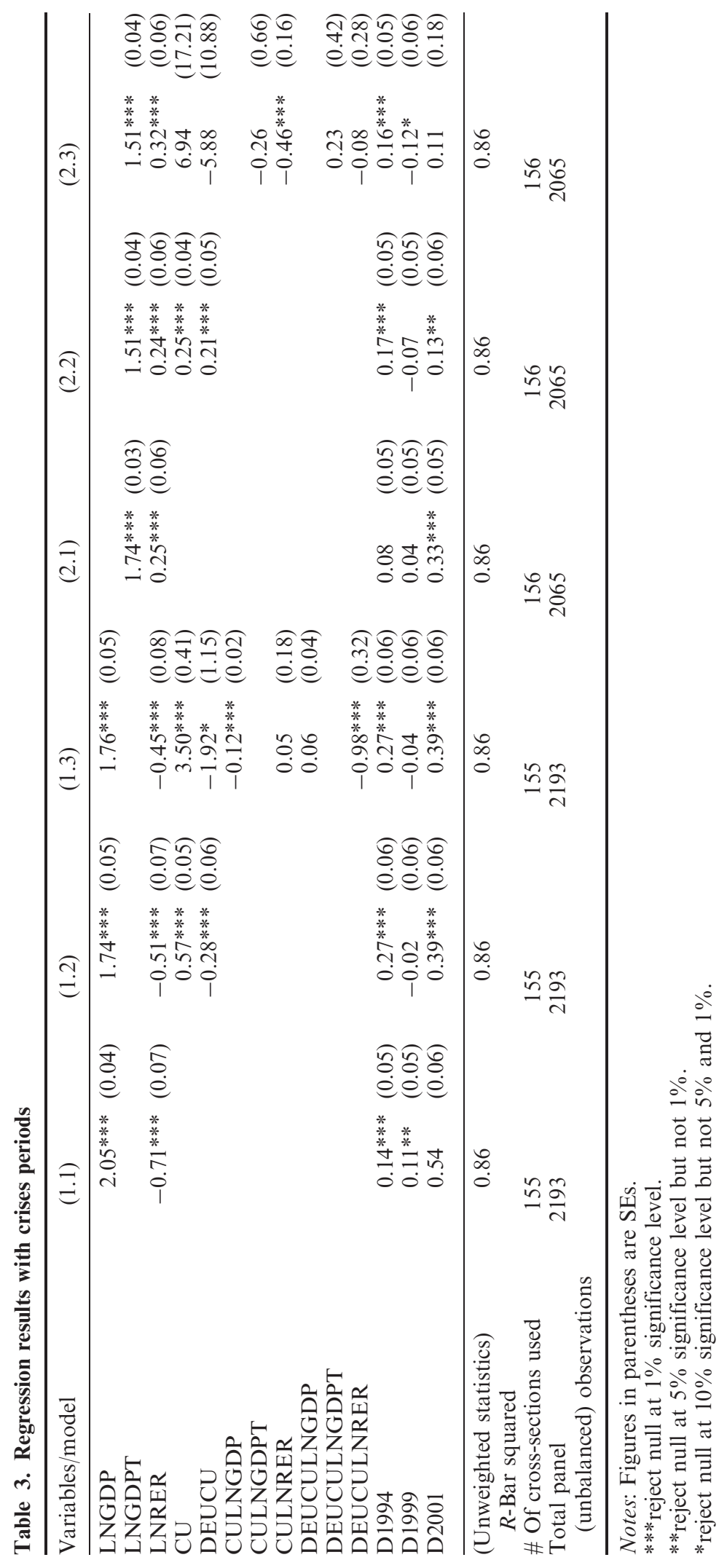


of domestic currency occurred on 5 April 1994, until which date imports sharply increased due to both highly overvalued domestic currency and expectations of devaluation prior to the break of the crisis. In 2001, the crisis and a sudden devaluation occurred in February 20 and hence there was a significant positive impact on export expansion that year. For the earthquake in 1999, which is not really an economic crisis and there was no sudden change of exchange rates, the only empirically significant effect is the decline on imports caused by a decrease in the aggregate demand level in the economy (significant only in Equation 2.3). ${ }^{17}$ Accounting for the major economic crises, however, do not alter our previously reported findings regarding the export and import behaviour before and after the CUA.

To confirm the robustness of our estimation results, the regressions reported above are also estimated separately for the EU and nonEU countries. The results of these estimations are reported in Table A4. The general nature of the results reported above for the full sample, namely the general increase in exports, but a more pronounced increase in exports to nonEU countries, and an increase in the overall imports, which is, however not robust for the EU countries, were all supported by the regressions using the sub-samples of countries. An overall increase in the income elasticity of exports; a significant increase in the price elasticity of exports to the EU countries; and a significant decrease in the price elasticity of imports from all, EU and nonEU countries are also all supported by the empirical findings based on estimation using these sub-samples.

It is thus possible to conclude that there was a significant effect of the $\mathrm{CU}$ on Turkish trade; both exports and imports increased during this period. Furthermore, changes have occurred in income and price elasticities of both exports and imports after the CU.

Although Ordinary least square (OLS) estimation causes inefficiencies in the estimation due to the use of a common intercept term for the large data set, we nevertheless also employed this methodology ${ }^{18}$ in order to be able to investigate the specific effects on trade of certain cross-section the specific factors such as the measures of political stability, governance ${ }^{19}$ or distance. OLS estimations show that exports of, but not imports from, Turkey have significantly increased after the CUA, but not for the EU countries per se.
These regressions also reveal the positive and significant effects of institutional factors, such as political stability and indicators of good governance such as rule of law, government efficiency and voice and accountability of the trading partners on Turkish exports and imports. ${ }^{20}$

\section{Conclusions}

Turkey's trade share with the European Union countries has been about $50 \%$ of its overall trade volume since the 1980s. Empirical evidence in this article shows that controlling for the effects of variables that are standard for the estimation of export and import demand functions, namely the RER and income levels, CU period has significantly augmented Turkey's trade. In addition, our estimations reveal that, as predicted by the theory, while the value of currency (measured by the RER) is negatively related with exports and positively related with imports, Turkish GDP is positively related with imports and GDP of trading partners are also positively related with Turkey's exports at statistically significant levels

Interestingly, while we observe that the income elasticity of both exports and imports are generally lower for the CU period, the effect of the RER on Turkey's exports is stronger for the EU countries after CU. However, RER changes cease to have a significant impact on imports after the CUA. In addition, especially the economic crisis of 1994 is observed to lead to substantial changes in export and import volumes, while the crises of 2001 has mainly affected exports. The magnitude of these changes appears to be beyond the indirect effects that occur through income and exchange rate changes that happen during the crises. Furthermore, we observe that countries with higher political stability and better governance have had more trade with Turkey than others.

We conclude that the CUA has contributed to the increasing volume of trade of Turkey, coupled with a decline in income elasticities of trade over the $\mathrm{CU}$ period. However, Turkish exports to, but not imports from, the EU have become more responsive to the RER misalignments during the CU period. A striking policy implication is therefore that periods of overvalued TL have come to carry a greater destabilizing

\footnotetext{
${ }_{18}^{17}$ See Selcuk and Yeldan (2001) for an analysis of the economic impact of the 1999 earthquake.

${ }^{18}$ Results are not reported but available from the author upon request.

${ }^{19}$ See Kaufman et al. (2002) for measures of political instability and estimates of governance variables based on an analysis of wide-ranging data sources - comprised of both polls and surveys conducted in individual countries.

${ }^{20}$ Regressions are available from the author upon request.
} 
risk for Turkish trade with the EU, for it leads to a larger fall in exports than before.

\section{References}

Baltagi, B. (1995) Econometric Analysis of Panel Data, John Wiley and Sons Ltd, New York.

Bayar, A., Nuray, H. and Recberoglu, S. (2000) The effects of the customs union on the Turkish economy, Economic Development Foundation, No. 160.

Baysan, T. and Blitzer, C. (1991) Turkey, in Liberalizing Foreign Trade: New Zealand, Spain, and Turkey (Eds) A. M. Choksi, M. Michaely, and D. Papageorgiou, St. Basil Blackwell, Inc, Cambridge, MA, pp. 263-405.

Bekmez, S. (2002) Sectoral impacts of Turkish accession to the European Union, Eastern European Economics, 40, $57-84$.

Berument, H. and Dincer, N. (2005) Denomination composition of trade and trade balance: evidence form Turkey, Applied Economics, 37, 1177-91.

Berument, H., Malatyali, K. and Neyapti, B. (2001) Turkey's full membership to the European Union: an analysis in view of business cycles, Russian and East European Finance and Trade, 37, 50-60.

Bond, M. E. (1987) An econometric study of primary commodity exports from developing country regions to the world, IMF Staff Papers, 34, 191-227.

Brada, J. C., Kutan, A. and Zhou, M. S. (1997) The exchange rate and the balance of trade: the Turkish experience, Journal of Development Studies, 33, 675-92.

Chacholiades, M. (1978) International Trade Theory and Policy, McGraw-Hill Book Company, New York.

Doroodian, K., Jung, C. and Yucel, A. (2002) Estimating the equilibrium real exchange rate: the case of Turkey, Applied Economics, 34, 1807-12.

Endoh, M. (2005) The effects of the GSTP on trade flow: mission accomplished?, Applied Economics, 37, 487-96.
Goldstein, M. and Khan, M. S. (1976) Large versus small price changes and the demand for imports, IMF Staff Papers, 23, 200-225.

Greene, W. H. (1993) Econometric Analysis, MacMillan Publishing Company, New York.

Harrison, G. W., Rutherford, T. F. and Tarr, D. G. (1996) Economic implications for Turkey of a customs union with the European Union, World Bank Policy Research Working Papers No. 1599, International Economics Department, International Trade Division, The World Bank.

Hausman, J. (1978) Specification tests in econometrics, Econometrica, 46, 1251-71.

Hsiao, C. (1986) Analysis of Panel Data, Econometric Society Monographs, Cambridge University Press, Cambridge, UK.

Kaufmann, D., Kraay, A. and Zoido-Lobaton, P. (2002) Governance Matters II: Updated Indicators for 2000/01, The World Bank.

Kennedy, P. (1997) A Guide to Econometrics, The MIT Press, Cambridge, MA.

Lipsey, R. G. (1997) The Theory of Customs Union: A General Equilibrium Analysis, London School of Economics and Political Science, Weidenfeld and Nicholson, London.

Mercenier, J. and Yeldan, E. (1997) On Turkey's trade policy: is a customs union with Europe enough?, European Economic Review, 41, 871-80.

Martinez-Zarzoso, I. and Nowak-Lehmann, F. (2003) Augmented gravity model: an application to Mercosur-European Union trade flow, Journal of Applied Economics, VI, 291-316.

Murray, T. and Ginman, P. (1976) An empirical examination of the traditional aggregate import demand model, Review of Economics and Statistics, 58, 75-80.

Ozlale, U. and Yeldan, E. (2004) Measuring exchange rate misalignment in Turkey, Applied Economics, 36, 1839-49.

Selcuk, F. and Yeldan, E. (2001) On the Macroeocnomic impact of August 1999 earthquake in Turkey: a first assessment, Applied Economics Letters, 8, 483-488. 


\section{Appendix}

Table A1. Real exchange rate (RER) and GDP of Turkey in terms of US Dollars

\begin{tabular}{lll}
\hline Year & RER $(1995=1)$ & $\begin{array}{l}\text { GDP (current } \\
\text { US\$, in billions) }\end{array}$ \\
\hline 1980 & 0.70 & 70.9 \\
1981 & 0.83 & 66.5 \\
1982 & 0.98 & 64.4 \\
1983 & 1.07 & 61.5 \\
1984 & 1.22 & 59.9 \\
1985 & 1.24 & 67.2 \\
1986 & 1.21 & 75.6 \\
1987 & 1.15 & 86.9 \\
1988 & 1.15 & 90.1 \\
1989 & 1.10 & 107.0 \\
1990 & 0.89 & 150.6 \\
1991 & 0.89 & 150.8 \\
1992 & 0.89 & 158.9 \\
1993 & 0.88 & 179.4 \\
1994 & 1.18 & 129.7 \\
1995 & 1.00 & 169.3 \\
1996 & 1.01 & 181.1 \\
1997 & 1.04 & 189.2 \\
1998 & 0.98 & 199.6 \\
1999 & 0.98 & 183.8 \\
2000 & 0.98 & 199.3 \\
2001 & 1.27 & 147.6 \\
\hline
\end{tabular}

Notes: RER has been calculated as: Nominal exchange rate (in terms of TL per Dollar) times the ratio of 1995 based CPI index of the USA, divided by the 1995 based CPI index of Turkey.

Table A2. Composition of Turkish manufacturing imports and exports

\begin{tabular}{|c|c|c|c|c|c|c|}
\hline & \multicolumn{3}{|c|}{ Share in EU } & \multicolumn{3}{|c|}{ Share in total } \\
\hline & 1995 & 1996 & 1999 & 1995 & 1996 & 1999 \\
\hline \multicolumn{7}{|l|}{ Panel A: Imports } \\
\hline Agricultural Products & 8.23 & 6.27 & 4.75 & 12.56 & 11.15 & 8.35 \\
\hline Mining Products & 7.10 & 5.94 & 4.02 & 18.79 & 18.52 & 17.53 \\
\hline Industrial Products & 84.47 & 87.38 & 90.93 & 68.38 & 69.97 & 73.57 \\
\hline Others & 0.20 & 0.41 & 0.30 & 0.27 & 0.36 & 0.55 \\
\hline Total & 100 & 100 & 100 & 100 & 100 & 100 \\
\hline \multicolumn{7}{|l|}{ Panel B: Exports } \\
\hline Agricultural Products & 18.55 & 17.97 & 14.32 & 21.05 & 21.31 & 16.70 \\
\hline Mining Products & 4.68 & 4.49 & 3.70 & 4.64 & 4.27 & 4.05 \\
\hline Industrial Products & 76.70 & 77.39 & 81.90 & 74.24 & 74.30 & 79.08 \\
\hline Others & 0.07 & 0.16 & 0.08 & 0.07 & 0.12 & 0.17 \\
\hline Total & 100 & 100 & 100 & 100 & 100 & 100 \\
\hline
\end{tabular}

Source: SIS, Statistical Institute of Turkey. 
Table A3. Wald test results for the significance of the sum of the coefficients in Tables 2 and 3, Equations 1.3 and 2.3

\begin{tabular}{|c|c|c|c|c|}
\hline Model & Null hypothesis & $\begin{array}{l}\text { Coefficient } \\
\text { sums }\end{array}$ & $F$-statistic & Probability \\
\hline \multicolumn{5}{|c|}{ Panel A: Table 2} \\
\hline \multirow[t]{4}{*}{ Export } & lnrer + culnrer $=0$ & -0.23 & 1.92 & 0.166 \\
\hline & lnrer + culnrer + deuculnrer $=0$ & -1.23 & $18.51 * * *$ & 0.000 \\
\hline & $\operatorname{lngdp}+$ culngdp $=0$ & 1.67 & $1315.35 * * *$ & 0.000 \\
\hline & $\operatorname{lngdp}+$ culngdp + deuculngdp $=0$ & 1.73 & $725.89 * * *$ & 0.000 \\
\hline \multirow[t]{4}{*}{ Import } & lnrer + culnrer $=0$ & -0.11 & 0.69 & 0.405 \\
\hline & lnrer + culnrer + deuculnrer $=0$ & -0.21 & 0.79 & 0.375 \\
\hline & $\operatorname{lngdpT}+$ culngdpT $=0$ & 1.00 & $13.92 * * *$ & 0.000 \\
\hline & $\operatorname{lngdp} T+$ culngdp $T+$ deuculngdp $T=0$ & 1.09 & $11.55 * * *$ & 0.001 \\
\hline \multicolumn{5}{|c|}{ Panel B: Table 3} \\
\hline \multirow[t]{4}{*}{ Export } & lnrer + culnrer $=0$ & -0.40 & $5.46^{* *}$ & 0.019 \\
\hline & lnrer + culnrer + deuculnrer $=0$ & -1.38 & $23.77 * * *$ & 0.000 \\
\hline & $\operatorname{lngdp}+$ culngdp $=0$ & 1.64 & $1183.43 * * *$ & 0.000 \\
\hline & $\operatorname{lngdp}+$ culngdp + deuculngdp $=0$ & 1.71 & $689.00 * * *$ & 0.000 \\
\hline \multirow[t]{4}{*}{ Import } & lnrer + culnrer $=0$ & -0.14 & 0.92 & 0.338 \\
\hline & lnrer + culnrer + deuculnrer $=0$ & -0.21 & 0.79 & 0.396 \\
\hline & $\operatorname{lngdp} T+$ culngdpT $=0$ & 1.25 & $3.59 *$ & 0.058 \\
\hline & $\operatorname{lngdpT}+$ culngdpT + deuculngdp $T=0$ & 1.48 & $4.34 * *$ & 0.037 \\
\hline
\end{tabular}

Notes: ***reject null at $1 \%$ significance level.

**reject null at $5 \%$ significance level but not $1 \%$.

*reject null at $10 \%$ significance level but not $5 \%$ and $1 \%$. 


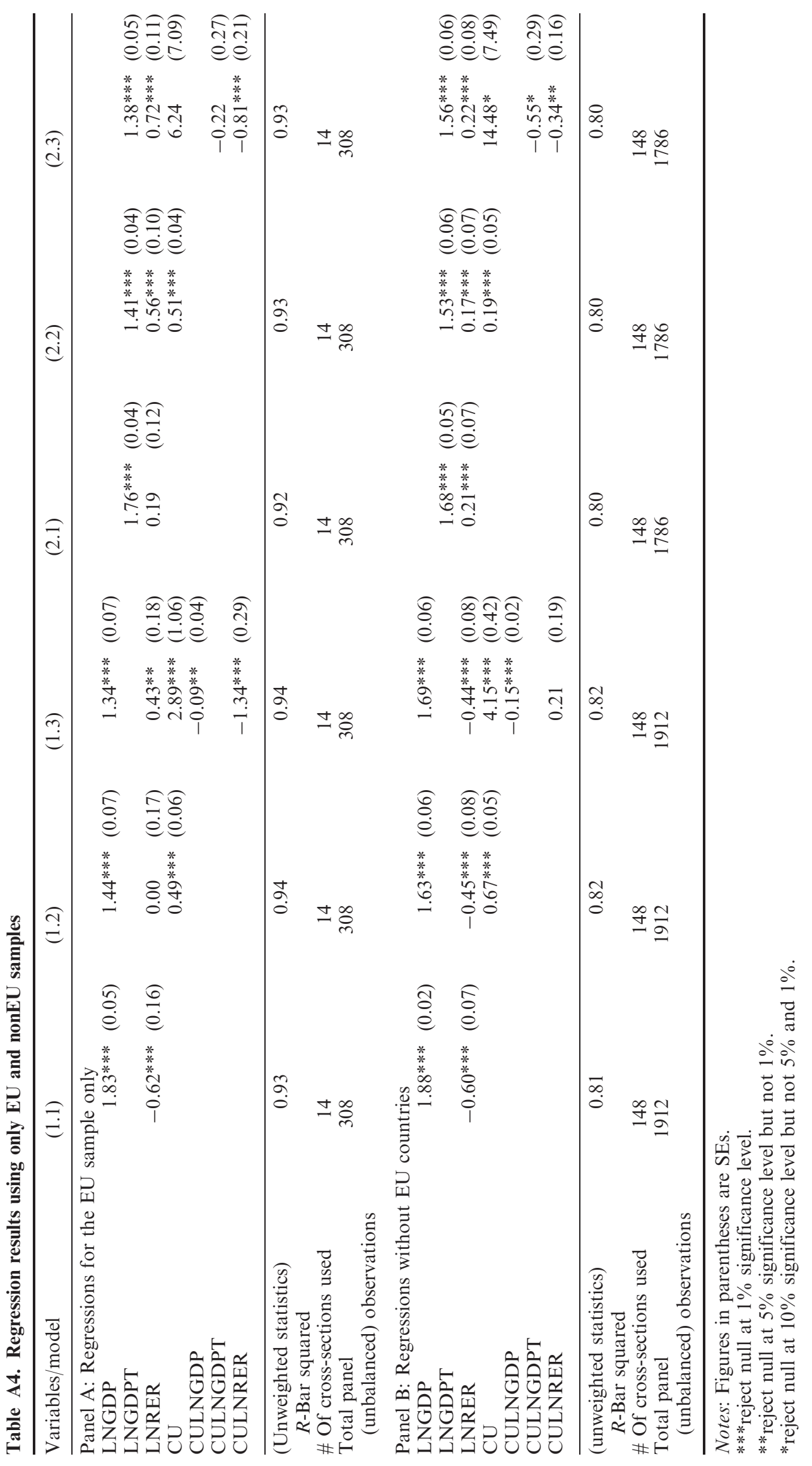

